\title{
PENGISIAN JABATAN SEKRETARIS DESA DI KABUPATEN BANYUMAS (Studi Tentang Kebijakan Pengisian Jabatan Sekretaris Desa)
}

\author{
Oleh: \\ Sri Hartini dan Abdul Aziz Nassihudin \\ Fakultas Hukum Universitas Jenderal Soedirman \\ E-mail: hartinimustika@gmail.com
}

\begin{abstract}
Village secretary assumed as a strategic occupation in the village government because the function as a proxy lead village. At the moment, Law No. 32 Year 2004 concerning Local Government have made arrangement this occupation status, which initially village secretary is not a public servant and now because some reasons will fill by Public Servant. How the policy of admission filling of this occupation? In the case, the government should make regulation which can guarantee the orderliness and protect the society.
\end{abstract}

Keyword: Village, village secretary and government policy

\section{A. Pendahuluan}

Para era globalisasi dan otonomi daerah seperti sekarang ini, secara umum pembangunan daerah diarahkan agar daerah mampu mandiri dalam hal pembiayaan pembangunan dan memiliki daya saing dengan darah lainnya. Namun demikian untuk mencapai kedua hal tersebut, kendali yang diharapi daerah sangatlah beragam, baik menyangkut faktor internal maupun eksternal. Untuk mencapai keberhasilan otonomi maka banyak daerah mengambil suatu kebijakan tertentu. Kebijakan yang diambil ini dimaksudkan sebagai dasar acuan untuk dapat melaksanakan tindakan tertentu. Salah satunya adlah membuat kewenangan susunan organisasi pemerintah yang didalamnya terdapat susunan organisasi desa.

Landasan pemikiran dalam pengaturan mengenai pemerintah desa adalah keanekaragaman, partisipasi, otonomi asli, dan pemberdayaan masyarakat. Dengan demikian pengaturan tentang otonomi daerah ini bertujuan menyelenggarakan otonomi dengan memberikan kewenangan yang luas, nyata dan bertanggung jawab. ${ }^{1}$ Desa sebagai organisasi pemerintah terendah dan merupakan posisi

HAW Widjaya, 2000, Pemerintah Desa Marga (Suatu Telaah Administrasi Negara). Jakarta: PT. RadjaGrafindo Persada, hlm. 6 yang terdekat dengan masyarakat merupakan tempat tumpuan segala urusan pemerintah yang berada di atasnya. Pemerintah desa harus mempunyai kemampuan yang memadai dalam Undang-Undang Nomor 32 tahun 2004 tentang Pemerintah Daerah.

Pemerintah desa terdiri atas kepala desa dan perangkat desa. Perangkat desa terdiri dari sekretaris desan dan perangkat desa. Perangkat desa berdasarkan Undang-Undang Nomor 32 tahun 2004 merupakan struktur organisasi dalam pemerintahan daerah yang ideal namun permasalahannya tidak semua desa di Indonesia mempunyai struktur organisasi desa dengan perangkat desa yang lengkap.

Dalam Undang-Undang Nomor 32 tahun 2004 mengantisipasi keadaan ini dengan maksud jangan sampai terjadi kekosongan jabatan di desa yang dapat mengakibatkan pemerintah desa menjadi labil. Dengan harapan kapanpun pemerintah desa tetap akan dapat menjalankan fungsinya. Hal ini sebagaimana diatur dalam pasal 202 yang mangatur tentang Pemerintah Desa sebagai berikut:

1. Pemerintah Desa terdiri dari kepala desa dan Perangkat desa;

2. Perangkat desa terdiri dari sekretaris desa dan perangkat desa lainnya; 
14 Jurnal Dinamika Hukum

Vol. 8 Januari 2008

3. Sekretaris desa sebagaimana dimaksud ayat (2) diisi oleh PNS yang memenuhi persyaratan.

Pasal 202 khususnya ayat (3) merupakan baru yang harus segera dilaksanakan. Ketentuan baru ini sangat mendesak untuk segera dapat irealisasikan, namun sampai dengan saat ini belum dapat dilaksanakan karena belum ada satu aturan yang dapat digunakan sebagai dasar pelaksanaannya.

\section{B. Perumusan Masalah}

Berdasarkan latar belakang di atas, maka dapat dirumuskan masalah sebagai berikut:

1. Langkah-langkah apa yang akan diambil oleh Pemerintah Daerah dalam mempersiapkan kebijakan jabatan sekretaris desa?

2. Bagaimanakah prosedur pengangkatan yang akan dilakukan dalam pengisian jabatan Sekretaris desa agar fungsi hukum terwujud?

\section{Metode Penelitian}

Metode penelitian yang digunakan untuk menjawab permasalahan adalah yuridis normatif dengan spesifikasi penelitian berupa deskriptif analitis. Sumber data utama pada penelitian ini adalah data sekunder yang berupa bahan hukum primer dan bahan hukum sekunder, serta bahan hukum tersier. Data yang diperoleh disajikan dalam uraian yang disusun secara sistematis. Data yang diperoleh dianalisis dengan teknik analisis bahan hukum normatif kualitatif.

\section{Pembahasan}

Sekretaris Desa merupakan bagian dari perangkat desa dan tercantum dalam Pasal 12 ayat (2) Peraturan Pemerintah No. 72 tahun 2005 tentang Desa yang menyatakan bahwa Perangkat desa terdiri dari Sekretaris Desa dan perangkat Desa lainnya. Berdasarkan Pasal 24, dalam melaksanakan tugasnya Perangkat Desa bertanggung jawab kepada Kepala Desa. Sedangkan dalam Pasal 25 menyebutkan bahwa Sekretaris Desa (sebagai bagian dari perangkat desa) diisi oleh Pegawai Negeri Sipil yang memenuhi persyaratan, yaitu : a. Berpendidikan paling rendah lulusan SMU atau sederajat;

b. Mempunyai pengetahuan tentang teknis pemerintahan;

c. Mempunyai kemampuan di bidang administrasi perkantoran;

d. Mempunyai pengalaman di bidang administrasi keuangan dan di bidang perencanaan;

e. Memahami sosial budaya masyarakat setempat, dan

f. Bersedia tinggal di desa yang bersangkutan.

Permasalahan yang timbul adalah sebelum dikeluarkan Peraturan Pemerintah ini, masih banyak Sekretaris Desa yang tidak berstatus sebagai Pegawai Negeri Sipil. Di Kabupaten Banyumas terdapat 301 desa yang didalamnya terdapat posisi Sekretaris Desa biasa yang tidak berstatus sebagai Pegawai Negeri Sipil. Berdasarkan hasil penelitian dapat diketahui bahwa dalam usulan pertama tahun 2006, Pemerintah Kabupaten Banyumas mengusulkan 27 orang Sekretaris Desa sebagai Calon Pegawai Negeri Sipil sedangkan mengenai pengang-katannya diserahkan seluruhnya pada kewenangan pusat.

1. Langkah-Langkah Yang Diambil Oleh Pemerintah Daerah Dalam Mempersiapkan Kebijakan Jabatan Sekretaris Desa

Kebijakan pengangkatan ini merupakan suatu terobosan baru guna memberikan penghormatan terhadap Sekretaris Desa yang selama ini telah berjasa dalam me-laksanakan kewajiban pegawai negeri namun tanpa disertai hak dan status yang sama dengan Pegawai Negeri Sipil lainnya. Salah satu bentuk kebijakan yang disambut antu-sias adalah teknis pengangkatan secara langsung terhadap Sekretaris Desa yang mem-punyai masa bakti yang telah memenuhi syarat dalam peraturan perundang-undangan yang berlaku.

Perbedaan karakteristik yang diberlakukan saat ini merupakan indikasi usaha pemerintah untuk bersikap adil terhadap warga negaranya.Pola pemikiran tersebut sesuai dengan filsafat "Quit Pro Quo" yang berarti "Sesuatu untuk sesuatu", atau dalam pepatah Indonesia berarti “Ada ubi ada talas, ada budi 
ada balas". Pola keadilan tersebut berawal pada pemikiran setiap Sekretaris Desa dalam hal menetapkan diri untuk memberikan "budinya" karena mereka meyakini sebelumnya bahwa mereka akan menerima "balas" yang setimpal dengan budi yang diberikan berupa status Pe-gawai Negeri Sipil, khususnya kepada Sekretaris Desa melalui prosedur pengangkatannya.

Mengenai langkah-langkah yang diambil oleh Pemerintah Daerah dalam mempersiapkan kebijakan jabatan Sekretaris Desa meliputi:

\section{a. Mengidentifikasi Jabatan Sekretaris Desa}

\section{1) Kepentingan Dalam Organisasi}

Kajian pertama yang dilakukan peneliti adalah pembahasan mengenai manu-sia sebagai pelaksana dari tugas Pegawai Negeri Sipil dalam mengisi jabatan sekretaris desa. Kajian ini digunakan untuk menggambarkan karakteristik manusia yang ditinjau dari faktor-faktor yang mempengaruhinya. Hal ini ditujukan untuk mengetahui tujuan pengangkatan Pegawai Negeri Sipil yang didasarkan pada kebutuhan dan kepentingan manusia didalamnya.

Manusia dalam kajian ekonomi disebut sebagai sumber daya karena memiliki kecerdasan. Melalui kecerdasan yang semakin meningkat mengakibatkan manusia dikatakan sebagai "homo sapies", homo politikus" dan "homo ekonomikus" dan kajian yang lebih mendalam dapat dikatakan pula bahwa manusia adalah zoon politicon. Berdasarkan perkembangan dalam dunia modern, maka dalam prosesnya, setiap individu akan berinteraksi dalam masyarakat yang semakin meluas dan perkembangan berikutnya adalah dimulainya konsep organisasi yang melingkupi bidang pemerintahan, sehingga manusia dapat dikatakan sebagai "homo administratikus" dan "organisazation man". ${ }^{2}$

Berdasarkan konteksnya sebagai homo administratikus, maka salah satu

Sondang P. Siagian, 1996, Filsafat Administrasi, Jakarta: PT. Gunung Agung, Cet ke-19, hlm. 9-10. bentuknya adalah pegawai dalam suatu organisasi. Pegawai dalam prosesnya memiliki perilaku awal yang dibentuk oleh lingkungan maupun pendidikannya. Perilaku dasar tersebut dapat berbeda dengan perilaku yang diinginkan oleh organisasi, dimana pegawai harus tunduk pada aturan-aturan yang berlaku di dalam organisasi sehingga dapat diarahkan pada tujuannya. Sehubungan dengan itu maka terhadap calon-calon pegawai diadakan latihan atau orientasi singkat mengenai aturan-aturan yang berlaku maupun latihan kerja.

Langkah-langkah yang ditempuh dalam suatu organisasi bertujuan untuk mempertautkan antara kepentingan pegawai dan organisasi. Kepentingan pegawai pada umumnya terbatas pada kepentingan memperoleh gaji guna memenuhi kebutuhanya dan hal inipun masih dipengaruhi oleh kepentingan lainnya berupa: keserasian arahan kerja dari pimpinan organisasi, kesempatan mengembangkan diri sampai dengan adanya jaminan di hari tua (pensiun). Identifikasi pengisian jabatan untuk sekretaris desa didasarkan pada teori kebutuhan manusia.

\section{2) Teori Kebutuhan Manusia}

Manusia mempunyai kebutuhan yang merupakan pemacu bagi dirinya untuk kebutuhanya, seperti bekerja untuk memperoleh uang bagi pemenuhan kebutuhan. Pada masyarakat yang hidupnya masih terbelakang, kebutuhan dipenuhi dari alam sekitarnya, sedangkan pada masyarakat yang maju telah terdapat diferensiasi tugas, pemenuhan dilakukan dengan membuat barang atau jasa.

Berdasarkan konteks pembahasan di atas, kebutuhan manusia dapat diklasifikasikan menjadi: kebutuhan fisiologis, sosial dan egoistik. Kebutuhan fisiologis adalah kebutuhan sandang, pangan, papan dan lain yang keseluruhanya bertujuan memenuhi kebutuhan dasar manusia yang disebut dengan kebutuhan 
primer. Manusia selalu berusaha agar kebutuhan primer dapat berkesinambungan, sehingga dalam hati nurani tumbuh harapan adanya kepastian dan keamanan. Kedua faktor ini yang menjadi dorongan yang kuat bagi manusia untuk bekerja.

Kebutuhan berikutnya adalah kebutuhan sekunder yang bersifat relatif, karena adanya perbedaan kebutuhan antara seseorang dengan lainnya. Menurut Flipo, kebutuhan tersebut yang terdiri dari: kebutuhan sosial dan ego, seperti: afeksi, disenangi oleh lingkungan. Kebutuhan ego tampak dalam berbagi kesempatan, seperti pengakuan terhadap kemampuan diri dari lingkungannya; sifat dominan dan lain-lain. Berdasarkan hal tersebut, maka seorang yang bekerja berorientasi pada pemenuhan kebutuhan primer dan apabila telah terpenuhi maka akan berkembang ke arah pemenuhan kebutuhan sekunder yang sulit untuk diukur.

Secara umum, tinjauan dari segi sosial ekonomi mengenai pegawai merupakan kesatuan yang kompleks. Pegawai atau tenaga kerja disebut sebagai "human resources" adalah manusia dalam usia kerja (working ages) yang mampu menyelenggarakan pekerjaan fisik atau pun mental. Hubungan manusia hendak-nya dilihat dari segi obyek dan tujuan yaitu manusia insani yang menjadi tujuan dari pada segala usaha, usaha mana yang dilakukan pula oleh manusia sebagai subyek atau pelaksananya. Manusia merupakan faktor atau sumber produksi yang berkewajiban memberikan hasil karyanya.

Berdasarkan pembahasan fungsi pegawai dalam konteks kepegawaan, maka hal ini berkenaan dengan Personel Administration. Personel artinya golongan masyarakat yang penghidupannya dilakukan dengan bekerja dalam kesatuan organisatorisnya yang salah satunya merupakan kesatuan kerja pemerintahan. Administration dalam konteks ini ber- beda dengan arti keterangan bahwa di dalamnya termatub organisation management dan realisasinya. Administration dalam konteks ini berbeda dengan arti Administrate. Berdasarkan kajiannya, maka tata administrasi kepegaian dalam hubungannya dengan Personel Administration berarti :

a) Tata yang menunjukan organization dan managemnt;

b) Administrasi yang memberi pengertian di samping pengertian administratie dalam bahasa Belanda juga dalam rangka pembinaan "organization dan management", sehingga meliputi pengertian usaha, hukum dan prosedur;

c) Pegawai yang mencakup pengertian Pegawai Negeri Sipil (pemerintah).

Pemahaman mengenai kepegawaian tersebut didasari oleh :

a) Bahwa administrasi suatu Negara adalah hasil produk dari pengaruh-pengaruh politik dan sosial sepanjang sejarah Negara yang bersangkutan, oleh karena itu suatu sistem administrasi tidak cukup dipahami dengan baik tanpa adanya pengetahuan administrasi dalam bentuk lampau. Perkembangan saat ini adalah negara akan mengembangkan administrasinya dengan sistem yang sama satu sama lain;

b) Menyesuaikan dengan pandangan J.G Ch. Volmer, ketika memper-kenalkan sistem Taylor di Negeri Belanda di mana menunjukan de relative gelding van taylor's leerselligen dalam penerapannya di Negeri Belanda yang mengemuka-kan tiga dasar pokok landasan pemikiran:

(1) Bahwa stelsel ini hanya diperuntukan sebagai "dienende middle" sebagai alat keperluan semata-mata untuk mencapai suatu kemajuan dalam usaha;

(2) Bahwa semua teori, pengetahuan, cara dan sistem serta alat-alat yang dipergunakan yang menyang- 
kut kehidupan ekonomis dalam praktek bersifat relatif, karena selalu berhubungan dengan keadaan-keadaan tertentu, tingkah laku manusia tertentu, kebiasaan-kebiasaan tertentu, kebutuhan-kebutuhan hidup tertentu, sehingga diperlukan pengetahuan mengenai keadaan, tingkah laku, kebiasaan dan kebutuhan hidup sebelum memilih dan menentukan usaha stelsel atau sistem dan alat keperluan untuk kemajuannya;

(3) Bahwa untuk penemuan stelsel atau sistem dan alat keperluan itu diperlukan suatu "zelfstandige overdenking van ieder problem onder gegevan omstandig-heden" ialah keharusan adanya pemikiranpemikiran yang berdiri sendiri dari tiap-tiap problema dalam keadaan tingkah laku, kebiasaan dan kebutuhan tersebut. $^{3}$

Berdasarkan analisa mengenai aspek manusia dihubungkan dengan teori-teori yang ada, maka penulis dapat menggambarkan bahwa hubungan ini meliputi kecenderungan pegawai untuk melaksanakan pekerjaannya berdasarkan kebutuhan manusia secara umum. Faktor motivasi yang timbul untuk memberikan prestasi, dipengaruhi oleh hukum tertulis yang membatasi setiap kepentingan dan adanya input berupa kontraprestasi yang sepadan terhadap pekerjaan yang dikerjakannya. Pengisian jabatan sekretaris desa mereflesikan pemberian prestasi terhadap aktivitas, baik secara moriil maupun dari sudut pandang hukum. Kebijakan dalam menempatkan subtansi norma dalam pengangkatannya merupakan penjabar-an dari maksud dan tujuan dalam organisasi guna pencapaian misinya. Dalam skala yang lebih luas merupakan refleksi dari tujuan negara menuju kesejahteraan masya-

Achmad Ichsan, 1981, Tata Administrasi Kekaryawanan Dasar-Dasar Socio Analitis, Jakarta: Penerbit Djambatan, hlm 4-5. rakat di dalam konteksnya melalui administrasi kepgawaian.

b. Mengkaji syarat-syarat administrasi dalam pengangkatan Sekretaris Desa berdasarkan peraturan perundang-undangan

Pengkajian terhadap syarat-syarat admiistrasi dala pengangkatan Sekretaris Desa meliputi :

1) Prosedur pengangkatan;

2) Seleksi administrasi (berkas);

3) Syarat lainnya.

c. Mendata dan mengusulkan pengangkatan Sekretaris Desa Kepada Pemerintah Pusat

Pengangkatan Sekretaris Desa merupakan kewenangan pusat di mana daerah hanya mempunyai hak untuk merekomendasi. Hal ini terkait dengan pembagian urusan pemerintahan. Pembagian urusan pemerintahan tersebut didasarkan pada pemikiran bahwa selalu terdapat berbagai urusan pemerintahan yang sepatutnya/tetap menjadi kewenangan pemerintah. Urusan pemerintah tersebut menyangkut terjaminnya kelangsungan hidup bangsa dan negara secara keseluruhan. Urusan pemerintah dimaksud meliputi: politik, luar negeri, pertahanan, keamanan, yustisi, moneter dan fiskal nasional, dan agama. Di samping itu terdapat bagian urusan pemerintah yang bersifat concurrent, artinya urusan pemerintahan yang penanganannya dalam bagian atau bidang tertentu dapat dilaksanakan bersama antara pemerintah dan pemerintah daerah. Dengan demikian setiap urusan yang bersifat concurrent senantiasa ada bagian urusan yang menjadi kewenangan pemerintah, ada bagian urusan yang diserahkan kepada Provinsi, dan bagian urusan yang diserahkan kepada Kabupaten/Kota.

Urusan mewujudkan pembagian kewenangan yang concurrent secara proporsional antara Pemerintah, Pemerintah Daerah Provinsi dan Pemerintah Kabupaten dan Kota, maka disusunlah kriteria yang meliputi: eksternalitas, akuntabilitas, dan efisiensi dengan mempertimbangkan keserasian hubungan pengelolaan urusan pemerintah antar tingkat pemerintahan. 
Kriteria akuntanbilitas adalah pendekatan dalam pembagian urusan pemerintah dengan pertimbangan bahwa tingkat pemerintahan yang menangani sesuatu bagian urusan adalah tingkat pemerintahan yang lebih langsung/dekat dengan dampak/ akibat dari urusan yang ditangani tersebut. Dengan demikian akuntanbilitas penyelenggaraan bagian urusan pemerintahan tersebut kepada masyarakat akan lebih terjamin.

Kriteria efisiensi adalah pendekatan dalam pembagian urusan pemerintahan dengan mempertimbangkan tersedianya sumber daya (personil, dana dan peralatan) untuk mendapatkan ketetapan, kepastian dan kecepatan hasil yang harus dicapai dalam penyelenggaraan bagian dan urusan. Artinya apabila suatu bagian urusan dalam penanganannya dipastikan akan lebih berdayaguna dan berhasilguna dilaksanakan oleh daerah Provinsi dan/atau daerah Kabupaten/Kota dibandingkan apabila ditangani oleh Pemerintah, maka bagian urusan tersebut tetap ditangani oleh Pemerintah. Untuk itu pembagian bagian urusan harus disesuaikan dengan memperhatikan ruang lingkup wilayah beroperasinya bagian urusan pemerintahan tersebut. Ukuran dayaguna dan hasilguna tersebut dilihat dari besar manfaat yang dirasakan oleh masyarakat dan besar kecilnya resiko yang harus dihadapi. Sedangkan yang dimaksud dengan keserasian hubungan yakni bahwa pengelolaan bagian urusan pemerintah yang dikerjakan oleh tingkat pemerintahan yang berbeda, bersifat saling berhubungan (interkoneksi), saling tergantung (interdependensi), dan saling mendukung sebagai satu kesatuan sistem dengan memperhatikan cakupan kemanfaatan.

Pembagian urusan pemerintahan sebagaimana tersebut di atas ditempuh melalui mekanisme penyerahan dan/atau pengakuan atas usul daerah terhadap bagian urusan-urusan pemerintah yang akan diatur dan diurusnya. Berdasarkan usulan tersebut pemerintah melakukan verifikasi terlebih dahulu sebelum mem-berikan pengakuan atas bagian urusan yang saat ini masih menjadi kewenangan pusat dengan kriteria tersebut dapat diserahkan kepada daerah. ${ }^{4}$ Dalam hal pembagian urusan pemerintahan terdapat suatu kewenangan yang melekat dari dalam pemerintah untuk membuat suatu kebijakan publik.

d. Membuat kebijakan terhadap Sekretaris Desa yang tidak memenuhi syarat administratif dalam pengangkatannya.

Amara Raksasataya mengemukakan Kebijaksanaan sebagai suatu taktik dan strategi yang diarahkan untuk mencapai tujuan. Suatu kebijaksanaan menuntut 3 (tiga) elemen yaitu :

1) Identifikasi dari tujuan yang ingin dicapai;

2) Taktik atau strategi dari berbagai langkah untuk mencapai tujuan yang diinginkan;

3) Penyediaan berbagai input untuk memungkinkan pelaksanaan secara nyata dari taktik strategi. ${ }^{5}$

Berdasarkan hal tersebut, kebijaksanaan akan menciptakan suatu kebijakan publik. Menurut Carl L. Friedrich adalah serangkaian tindakan yang diusulkan seseorang, kelompok atau pemerintah dalam suatu lingkungan tertentu, dengan ancaman dan peluang yang ada, di mana kebijakan yang diusulkan tersebut ditujukan untuk memanfaatkan potensi sekaligus mengatasi hambatan yang ada dalam rangka mencapai tujuan tertentu. ${ }^{6}$ Riant Nugroho mengungkapkan jenis-jenis dari kebijakan publik. Kebijakan publik dalam bentuknya dapat dibagi menjadi dua jenis, yaitu kebijakan publik dalam bentuk peraturan peraturan pemerintah yang tertulis dalam bentuk peraturan-peraturan dan peraturan-peraturan pemerintah yang tidak tertulis namun di-

4 Penjelasan Umum Undang-Undang Nomor 32 Tahun 2004 tentang Pemerintahan Daearah.

5 Islamy M. Irfan, 2000, Prinsip-Prinsip Perumusan Kebijaksanaan Negara, Jakarta: Bumi Aksara, hlm. 2-3.

6 D. Riant Nugroho, 2003, Kebijakan Publik :Formulasi, Implementasi dan Evaluasi, Jakarta: Elex Media Komputindo, hlm. 4. 
sepakti, yaitu yang disebut sebagai konvensi-konvensi. ${ }^{7}$

Adanya permasalah yang timbul di masyarakat merupakan agenda tetap bagi pemerintah untuk mencari solusi yang terbaik dalam pemecahannya berupa kebijakan. Ciri-ciri khusus yang melekat dalam pada kebijakan adalah :

1) Kebijakan lebih merupakan tindakan yang mengarah pada tujuan daripada sebagai perilaku atau tindakan yang serba acak dan kebetulan, dan merupakan tindakan yang direncanakan;

2) Kebijakan pada hakikatnya terdiri atas tindakan-tindakan yang salin terkait dan berpola mengarah pada tujuan tertentu yang dilakukan oleh pejabat-pejabat pemerintah dan bukan merupakan keputusan-keputusan yang berdiri sendiri;

3) Kebijakan bersangkut paut dengan apa yang senyatanya dilakukan pemerintah dalam bidnag-bidang tertentu;

4) Kebijakan mungkin berbentuk positif, mungkin pula negatif. Dalam bentuknya yang positif, kebijakan negara mungkin akan mencakup beberapa bentuk tindakan pemerintah yang dimaksudkan untuk mempengaruhi masalah tertentu, sementara dalam bentuknya yang negatif, kebijakan kemungkinan meliputi keputusan-keputusan pejabat pemerintah untuk tidak melakukan tindakan apapun dalam masalah-masalah di mana campur tangan pemerintah justrus diperlukan. ${ }^{8}$

Dalam hal ini, pemerintah daerah akan menciptakan suatu kebijakan terhadap Sekretaris Desa yang tidak memenuhi persyaratan administratif untuk mendapatkan hak-hak menjadi Pegawai Negeri Sipil. Ini merupakan alternatif pemberian prestasi terhadap kinerja yang telah diberikan oleh para Sekretaris Desa.

2. Prosedur Pengangkatan yang akan Dilakukan dalam Pengisian Jabatan Sekretaris Desa untuk Mewujudkan Fungsi Hukum

Ibid, hlm. 57

Ibid, hlm. 16-17.
Pengangkatan Sekretaris Desa menjadi Pegawai Negeri Sipil di dasarkan kewenangan yang dimiliki oleh pusat melalui Pejabat Pembina Kepawaian. Pejabat Pembina Kepagawaian adalah Pejabat yang berwenang mengangkat, memindahkan dan menghentikan Pegawai Negeri Sipil di lingkungannya sesuai dengan peraturan perundang-undangan. Dalam hal ini Pemerintah Daerah hanya mendata dan mengusulkan jumlah Sekretaris Desa yang memenuhi syarat sebagai Calon Pegawai Negeri Sipil dan merekomendasikan mereka kepada pusat.

Pengangkatan Sekretaris Desa didasarkan pada usia dan masa kerja dengan kriteria sebagai berikut:

a. Sekretaris Desa yang berusia paling tinggi 46 (empat puluh enam) tahun dan mempunyai masa kerja 20 (dua puluh) tahun atau lebih secara terus menerus;

b. Sekretaris Desa yang berusia paling tinggi 46 (empat puluh enam) tahun dan mempunyai masa kerja 10 (sepuluh) tahun atau lebih sampai dengan kurang dari 20 (dua puluh) tahun secara terus menerus;

c. Sekretaris Desa yang berusia paling tinggi 40 (empat puluh) tahun dan mempunyai masa kerja 5 (lima) tahun atau lebih sampai dengan kurang dari 10 (sepuluh) tahun secara terus menerus;

d. Sekretaris Desa yang berusia paling tinggi 35 (tiga puluh lima) tahun mempunyai masa kerja 1 (satu) tahun atau lebih sampai dengan kurang dari 5 (lima) tahun secara terus menerus.

Dalam proses pengangkatan Sekretaris Desa dilakukan melalui seleksi administrasi, disiplin, integritas, kesehatan dan kompetensi di mana Sekretaris Desa yang akan diangkat menjadi Pegawai Negeri Sipil wajib mengisi/menjawab daftar pertanyaan mengenai pengetahuan tata pemerintahan/kepemerintahan yang baik.

Pengangkatan Sekretaris Desa dilakukan secara obyektif dan transparan yang pada dasar prinsipnya memprioritaskan Sekretaris Desa yang berusia paling tinggi dan/atau mempunyai masa kerja lebih banyak, di mana Sekretaris Desa yang akan diangkat adalah Sekretaris Desa 
adalah yang telah bertugas sebelum tanggal 30 Oktober 2005. konsekuensi logisnya adalah Sekretaris Desa yang bbertugas setelah 30 Oktober 2005 tidak dapat dikategorikan sebagai Sekretaris Desa yang akan diangkat menjadi Pengawai Negeri Sipil.

Pengangkatan Sekretaris Desa menjadi Calon Pegawai Negeri Sipil dilakukan bertahap mulai Tahun Anggaran 2005 dan paling lambat selesai Tahun 2009, dengan prioritas Sekretaris Desa yang penghasilannya dibiayai oleh Anggaran Pendapatan dan Belanja Negara dan Anggaran Pendapatan dan Belanja Daerah.

Untuk kelancaran pelaksanaan pengangkatan Sekretaris Desa menjadi Calon Pegawai Negeri Sipil dibentuk Tim Koordinasi Tingkat Nasional dan Tim Tingkat Instansi. Tim Koordinasi Tingkat Nasional ditetapkan oleh Menteri yang bertanggung-jawab di bidang pendayagunaan aparatur negara. Tim Tingkat Instansi ditetapkan oleh Pejabat Pembina Kepegawaian yang bersangkutan.

Untuk pelaksanaan pengangkatan Sekretaris Desa menjadi Calon Pegawai Negeri Sipil tingkat instansi daerah Kabupaten/Kota dikoordinasikan oleh Gubernur. Biaya yang diperlukan bagi pelaksanaan pengangkatan Sekretaris Desa menjadi Calon Pegawai Negeri Sipil Tahun Anggaran 2005 sampai dengan Tahun Anggaran 2009 dibebankan pada Anggaran Pendapatan dan Belanja Negara Sekretaris Desa yang tidak memenuhi semua syarat di atas. Atas dasar kebijakan pemerintah daerah akan di gaji dan diberi pensiun dengan dana bengkok.

\section{E. Penutup}

Beberapa simpulan yang dapat diambil berdasarkan pembahasan tersebut di atas adalah:

1. Langkah-langkah apa yang diambil oleh Pemerintah Daerah dalam mempersiapkan kebijakan, jabatan Sekretaris Desa :

a. Mengidentifikasi Jabatan Sekretaris Desa;

b. Mengkaji syarat-syarat administrasi dalam pengangkatan Sekretaris Desa berdasarkan peraturan perundang-undangan; c. Mendata dan mengusulkan pengangkatan Sekretaris Desa kepada Pemerintah Pusat;

d. Membuat suatu kebijakan terhadap Sekretaris Desa yang tidak memenuhi syarat administratif dalam pengangkatannya.

2. Prosedur pengangkatan yang dilakukan dalam pengisian jabatan Sekretaris Desa sehingga fungsi hukum terwujud, antara lain:

a. Seleksi administrasi;

b. Sekretaris Desa yang diangkat menjadi Pegawai Negeri Sipil adalah Sekretaris Desa yang telah bertugas sebelum tanggal 30 Oktober 2005, sedangkan yang bertugas setelah 30 Oktober 2005 tidak dapat diangkat menjadi Pegawai Negeri Sipil;

c. Sekretaris Desa yang tidak memenuhi semua syarat, maka terdapat kebijakan pemerintah daerah dengan menggaji dan memberikan pensiun dari tanah bengkok;

d. Pemerintah Daerah hanya mendata dan mengusulkan sedangkan kewenangan pengangkatan diserahkan kepada pusat.

\section{Daftar Pustaka}

Hartono, Sunaryati. 1994. Penelitian Hukum di Indonesia Pada Akhir Abad ke-20. Bandung: Penerbit Alumni;

Ichsan, Achmad. 1981. Tata Administrasi Kekaryawanan Dasar-Dasar Socio Analitis. Jakarta: Penerbit Djambatan;

Irfan, Islamy M. 2000. Prinsip-Prinsip Perumusan Kebijaksanaan Negara. Jakarta: Bumi Aksara;

Nugroho, D. Riant. 2003. Kebijakan Publik: Formulasi, Implementasi dan Evaluasi. Jakarta: Elex Media Komputindo;

Siagian, Sondang P. 1996. Filsafat Administrasi, Jakarta: PT. Gunung Agung;

Soemitro, Ronny Hanitijo. 1988. Metodologi Penelitian Hukum. Jakarta: Ghalia Indonesia;

Widjaya, HAW. 2000. Pemerintah Desa Marga (Suatu Telaah Administrasi Negara). Jakarta: PT. RadjaGrafindo Persada. 